УДК 342.9

DOI https://doi.org/10.32837/pyuv.v2i4(29).443

\author{
B. А. Капличний \\ orcid.org/0000-0002-5798-945X \\ здобувач відділу публічного права \\ Науково-дослідного інституту публічного права
}

\title{
НЕДОЛІКИ ЗАКОНУ УКРАЇНИ «ПРО ФІЗИЧНУ КУЛЬТУРУ І СПОРТ»
}

Сучасні реалії та виклики сьогодення зобов'язують державотворця дещо в іншому векторі поглянути на необхідність захисту здоров'я населення. Маємо на увазі саме розвиток соціально-культурної сфери, напрямом якої є спорт. Сьогодні однією з головних проблем є погіршення фізичного здоров'я населення, апатія до фізичного навантаження, постійна зайнятість і брак часу на власне здоров'я, небажання витрачати фізичні сили й час на власне здоров'я. Усе це є негативними чинниками, що згубно впливають на рівень здоров'я нації, їі рухову активність, зниження рівня зацікавленості та спортивної освіченості підростаючого покоління, збільшення чисельності хворих i, відповідно, зниження здорової частини населення, розвиток і розширення видів хвороб тощо.

Одним із дієвих кроків на шляху до вирішення означених проблем $є$ саме ефективна та результативна робота нормотворця. Наявність дієвої системи нормативно-правових актів є запорукою збалансованого розвитку всіх сфер і галузей життєдіяльності населення. Утім, незважаючи на писані закони юридичної техніки, усе ж таки варто констатувати наявність у правовому полі прогалин і колізій у законодавстві або й узагалі відсутність норм, які б урегульовували ту чи іншу групу суспільних відносин у сфері спорту. Нині нашим завданням є дослідження системи нормативно-правових актів, якими врегульовуються відносини в досліджуваній нами сфері, і внесення можливих пропозицій щодо вдосконалення окремих її норм.

Науковці у сфері спорту неоднозначно підходять до визначення основ нормативно-правового регулювання у сфері спорту. Здебільшого їхня наукова позиція виходить із того, що вони виокремлюють за певними ознаками не просто сферу спорту, а самостійну галузь спортивного права.

Р. Чередник, будучи прибічником теорії спортивного права, стверджує, що правове регулювання у сфері спорту має низку особливостей, що зумовлені як предметом, себто доволі широким колом суспільних відносин, які виникають у сфері спорту, так і переважаючим методом - диспозитивним. Регулювання у сфері спорту здійснюється великим за обсягом і значною мірою неупорядкованим масивом правового матеріалу, який охо- плює як національне, так і міжнародне законодавство. У цьому контексті вельми змістовною $\mathrm{\epsilon}$ концепція «soft law», що активно застосовується для правового регулювання суспільних відносин у сфері спорту в багатьох країнах світу. Також перспективним з погляду визначення перспектив правового регулювання у сфері спорту та шляхів удосконалення законодавства $є$ розгляд доцільності прийняття Спортивного кодексу України (за аналогією Спортивного кодексу Франції [1] правового акта, що регулює суспільні відносини у сфері спорту в цій країні) [2, с. 561]. Утім з пропозицією щодо доцільності прийняття Спортивного кодексу України дуже важко погодитися. По-перше, виникає питання, до якої галузі права буде належати виокремлена автором галузь спортивного права? До публічного чи приватного? Однозначну відповідь на це питання надати не можна, адже, відповідно до норм чинного Закону України «Про фізичну культуру і спорт», у сфері спорту є відносини, які врегульовуються приватним правом, a $€$ відносини, які врегульовуються публічним правом. По-друге, уважаємо недоречним бездумне «плодіння» усіляких кодифікованих актів, що пропонують прийняти, особливо коли мова йде про неможливість поєднання в одному кодексі норм, які належать до різних галузей права. Убачається за можливе все ж таки звертатися до кодифікованих (наприклад, Кодекс законів про працю, Цивільний кодекс України тощо) чи законодавчих актів з того чи іншого питання.

Цікаве, на нашу думку, визначення поняття «фізкультурно-спортивне законодавство» надає I. Рибчич - як міжгалузевий за природою нормативно-правовий комплекс норм, призначений регулювати специфічну сферу суспільних відносин, що виникають у процесі організації та здійснення спортивної й фізкультурної діяльності, а також щодо реалізації в цій сфері політики органами публічної влади України [3, с. 8]. І. Рибчич відходить від єдиного розуміння галузі спортивного права, на рівні із законодавцем поєднуе сферу, яка сприяє фізичному розвиткові особи у сфері фiзичної культури та спорту.

О. Завальнюк, поширюючи теорію спортивного права, розглядає законодавство про фізичну культуру і спорт в Україні як комплексну й значну за обсягом частину законодавства України, 
що включає норми конституційного, цивільного, трудового, міжнародного права, норми адміністративного, господарського, процесуального податкового права, які стосуються державного управління в галузі спорту. Також науковець акцентує увагу, що система національного законодавства в галузі спорту є досить громіздкою, розгалуженою та недостатньо ефективною [4, с. 135 , с. 139$]$.

М. Ткалич, досліджуючи законодавство у сфеpi спорту, указує на його застарілість і невідповідність потребам сучасного спорту й суспільства. Відповідно, пропонує доповнити Закон України «Про фізичну культуру і спорт» такими поняттями, як «професійна спортивна ліга», «професійні спортивні змагання», «професійний спортивний клуб», «спортивний агент», «спортивна санкція», «організатор спортивного змагання», а також нормами, що врегулюють питання професійного спорту на законодавчому рівні, які фактично не врегульовані [5].

Багато західних спеціалістів справедливо вважають, що правове регулювання спорту є однією зі складних і важливих проблем. Потрібно створити в ньому таку систему правових відносин, яка не лише задовольняла б суб'єктів, а й сприяла зростанню майстерності спортсменів, залученню уваги 3MI, спонсорів, глядачів [6, с. 13; 7, с. 136].

Отже, уважаємо, що нормативно-правове регулювання у сфері спорту - ие систела законодавчих $і$ підзаконних норлативно-правових актів, які врегульовують суспільні відносини щодо організаиї та проведення спортивних заходів i злагань, забезпечення рухової активності людей різних вікових груп і фізичного стану під час їхнього дозвілля для зліинення здоров'я, сприяють інфорлаиійній обізнаності населення щодо зайнятості спортивною ділльністю.

С. Нікітенко відзначає, що правовими нормами визначена організація роботи з популяризації фізичної культури і спорту серед населення (масове фізичного виховання, проведення навчально-тренувальних занять, спортивних змагань тощо), спорту високих досягнень, також регламентується діяльність спортивних організацій [7, с. 97]. Крім того, С. Нікітенко акцентує увагу на значенні актів органів місцевого самоврядування та колегіальних рішеннях громадських організацій у сфері спорту.

М. Пєшин і Б. Бомановський поділяють систему нормативно-правових актів у сфері спорту на три групи: загальнодержавні акти (закони, акти Верховної Ради України, акти Президента України); акти суб'єктів виконавчої влади й акти муніципальних органів [8].

0. Алікова традиційно систему нормативно-правового регулювання у сфері спорту пропонує поділяти на законні й підзаконні акти, які приймають державні органи [9, с. 211]. Ця позиція є класично та доцільною, однак, на нашу думку, необхідно доповнити їі міжнародно-правовими актами у сфері спорту, які ратифікувала Україна.

Отже, систела норлативно-правових актів у сфері спорту, на нашу дулку, поділяється на міжнародні акти; норли фундалентальні, які визначать пріоритетність зайняття спортом, різні види спортивної діяльності, популяризують спорт на міжнародній арені та сприяють спортивному процвітанню й досягненням у спорті, і норли спеиіального законодавства, тобто система актів, які врегульовують відносини щодо особливостей зайняття певним видом спорту, визначають та організовують порядок здійснення спортивної діяльності.

Статтею 2 Закону України «Про фізичну культуру і спорт» визначено, що законодавство України про фізичну культуру і спорт базується на Конституції України і складається із цього Закону, відповідних міжнародних договорів України й інших нормативно-правових актів, що регулюють правовідносини в цій сфері [10, ст. 2]. Отже, цей законодавчий акт за своїм характером є спеціальним і повинен урегульовувати суспільні відносини, що виникають у сфері спорту. Однак чинний Закон України «Про фізичну культуру і спорт» не відповідає реаліям сьогодення. Оскільки в Україні проводиться робота, спрямована на інтеграцію й адаптацію законодавства України до законодавства Європейського співтовариства, назріла нагальна потреба викласти вищезазначений Закон у новій редакції. Новий Закон України «Про фізичну культуру і спорт» має відобразити сучасні підходи до розвитку фізичної культури і спорту, клубної системи, забезпечення збірних команд України тощо [11, с. $13 ; 4$, с. 138]. Також цим актом має бути закладено підвалини розуміння утвердження в суспільстві необхідності пропаганди здорового способу життя, залучення більш широких верств населення незалежно від віку і стану здоров'я, створення форм залучення молоді займатися своїм фізичним здоров'ям, а зайнятість молоді спортом буде запобігати вчиненню правопорушень у молодіжному й підлітковому середовищі, що як результат позитивно відобразиться на соціально-економічному розвитку України.

Саме тому на основі аналізу положень Закону України «Про фізичну культуру і спорт» хотілося $б$ акцентувати увагу на наявних прогалинах і колізіях.

По-перше, базовими категоріями цього акта є фізична культура та спорт, а визначення поняття «спорт» включає ознаки фізичної культури. Так, у ст. 1 Закону України «Про фізичну культуру i спорт» наведено визначення поняття «спорт», під яким законодавець пропонує розуміти діяльність 
суб’єктів сфери фізичної культури і спорту, спрямована на виявлення й уніфіковане порівняння досягнень людей у фізичній, інтелектуальній та іншій підготовленостях шляхом проведення спортивних змагань і відповідної підготовки до них. Спорт має такі напрями: дитячий спорт, дитячо-юнацький спорт, резервний спорт, спорт вищих досягнень, професійний спорт, спорт ветеранів, олімпійський спорт, неолімпійський спорт, службово-прикладний i військово-прикладний спорт, спорт осіб з інвалідністю тощо [2, ст. 1].

У цьому разі ми маємо на увазі такі ознаки фізичної культури: 1) можливість участі суб’єктів фізичної культури в спорті. На нашу думку, це не є закономірним, адже суб'єкти фізичної культури та спорту є різними. Також головною ознакою фізичної культури є мета - забезпечення рухової активності фізичної особи й популяризація та вчинення заходів щодо здорового способу життя, тоді як головна мета спорту - це саме організація й проведення спортивних змагань, за результатами яких виявити й, відповідно, порівняти досягнення спортсменів; 2) суб'єктом спорту є спортсмен, тоді як суб'єктом фізичної культури є фізична особа, яка бажає бути здоровою; 3) головна ознака, яка відмежовує фізичну культуру від спорту, - систематичність (притаманна саме спорту). Отже, на нашу думку, необхідно уніфікувати поняття cnopm і визначити його $九 \kappa$ сферу соціально-культурної ділльності особи, яка спрялована на систелатичну підготовку до спортивних злагань та участь у іх проведенні, ведення здорового способу життя, що сприятиме становленню фізично й психологічно здорової особистості.

По-друге, статтею 5 Закону визначено перелік суб’єктів, які здійснюють державне управління у сфері спорту. Зокрема, їх поділено на: 1) державні органи (центральні й місцеві органи виконавчої влади) та 2) органи місцевого самоврядування. Водночас у ст. 6 визначено повноваження лише центральних органів виконавчої влади, при цьому ані повноважень місцевих органів виконавчої влади, ані повноважень органів місцевого самоврядування законодавець не визначив. Хоча, на наше переконання, в умовах децентралізації суб'єктами, які безпосередньо реалізують державну політику у сфері спорту, є саме місцеві органи публічної адміністрації, а також ці органи є найбільш наближеними до суб'єктів сфери спорту. Саме тому вважаємо за обов'язкове визначити повноваження місцевих органів виконавчої влади й органів місцевого самоврядування в цьому Законі шляхом доповнення ст. 6-1 і ст. 6-2 такого змісту:

«Стаття 6-1 Повноваження місиевих органів виконавчої влади у сфері фізичної культури і спорту

- розроблення та прийняття регіональних про грал розвитку спорту, організація їх виконання;
- організація й проведення обласних і місиевих спортивних заходів;

- здійснення фінансування в межах програм розвитку фізичної культури і спорту;

- сприяння розвитку національних видів спорту, розвиток дитячо-юнацького спорту з летою створення улов для підготовки спортивних збірних коланд, а також масового спорту;

- забезпечення діяльності регіональних иентрів спортивної підготовки».

«Стаття 6-2 Повноваження органів місиевого самоврядування

1) розроблення, прийняття й реалізація лісие вих програл розвитку фізичної культури і спорту;

2) інфорлування та популяризаиія фізичної культури і спорту серед різних груп населення;

3) організація проведення муніципальних офіційних фізкультурних заходів $і$ спортивних заходів;

4) розроблення, прийняття й виконання календарних планів фізкультурних заходів і спортивних заходів муніципальних утворень;

5) сприяння розвитку діяльності суб'єктів сфери фізичної культури і спорту, а також створення дитячо-юнацьких спортивних шкіл, спеціалізованих навчальних закладів спортивного профілю, центрів олілпійської підготовки тощо;

6) здійснення контролю й нагляду за дотриланнял суб'єктали сфери фізичної культури і спорту порядку їхньої діяльності».

По-третє, розділ 2 Закону має назву «Суб’єкти сфери фізичної культури і спорту», де перераховані всі можливі організаційні форми участі особи (фізичної чи юридичної) у сфері спорту. Так, безпосередньо суб'єкти сфери фізичної культури і спорту можуть здійснювати свою діяльність як громадські організації; бути структурним елементом центрального органу виконавчої влади чи підприємства, установи, організації та їх об’єднання; фізична особа. Утім норми чинного законодавства не надають чіткого визначення спортивної організації, що, відповідно, ускладнює визначення правового статусу цього суб'єкта. Також у розділі 2 перераховані суб'єкти викладені хаотичному порядку, тобто немає відмежування суб'єктів сфери фізичної культури і спорту, які діють як громадські організації, а які діють у складі підприємства, чи установи, чи органу центральної виконавчої влади.

По-четверте, ст. 18 Закону визначено можливість зайняття фізичною культурою та спортом колективами працівників певного підприємства, установи чи організації, що здійснюється з метою здійснення фізкультурно-оздоровчої діяльності за місцем роботи громадян. Такі колективи можуть бути осередками фізкультурно-спортивних товариств. Колективи фізичної культури можуть здійснювати фізкультурно-оздоровчу діяльність 
за рахунок членських внесків, коштів власника відповідних підприємств, установ, організацій i/або коштів профспілкової організації відповідних підприємств, установ, організацій, отриманих від роботодавця на фізкультурно-оздоровчу діяльність відповідно до законодавства [10, ст. 18]. Закон навіть у ст. 28 визначає обов'язок керівників усебічно сприяти й заохочувати своїх працівників до зайняття масовим спортом. Проте натепер варто відзначити, що більшість керівників підприємств, установ та організацій не зацікавлені в виділенні фінансування на розвиток закладів фізичної культури і спорту, які знаходяться на балансі, за можливості закривають і перепрофільовують їх, тим самим передаючи площі, зайняті під зайняття фізичною культурою і спортом, в оренду й отримуючи із цього фінансову вигоду. Саме тому ми пропонуємо на законодавчому рівні закріпити заборону керівникам підприємств, установ та організацій передавати в оренду, закривати чи перепрофільовувати приміщення, які виділені під зайняття фізичною культурою та спортом, шляхом унесення доповнень до ст. 28 і доповнити цю норму ч. 3 такого змісту:

"Cmamms 28

ч. 3 Керівники підприєлств, установ та організаиій зобов'язані вживати необхідні заходи для збереження інфраструктури фізкультурнооздоровчої та спортивно-ласової роботи за лиісием навчання, роботи, проживання й відпочинку населення. Забороняється без законодавчого обгрунтування закриття й перепрофілювання зазначених закладів і структурних підрозділів».

По-п'яте, сфера фізичної культури і спорту є одним із пріоритетних напрямів гуманітарної політики держави. Спорт має велику кількість видів, а безпосередньо зайняття спортом передбачає використання певних спортивних споряджень, приладів, предметів тощо. Також однією 3 особливостей зайняття спортом є місце проведення спортивних занять. 3 положень Закону є очевидним різносторонність спорту та багатогранність можливостей особи, яка займається спортом. Разом із тим держава повинна не лише захищати право особи на зайняття фізичною культурою та спортом, а й забезпечувати безпечність зайняття цим видом діяльності. У цьому разі ми маємо на увазі законодавчо регламентовані засоби публічного адміністрування, які держава використовує у сфері спорту з метою захисту прав і законних інтересів спортсмена. Утім, проаналізувавши норми Закону, ми переконалися, що його норми не декларують положення, що стосуються порядку реалізації уповноваженими суб'єктами засобів публічного адміністрування у сфері спорту, наприклад, ліцензування навчальних закладів, у яких здійснюється підготовка фахівців сфери фізичної культури і спорту; акредитація навчальних закла- дів у сфері фізичної культури і спорту; сертифікація спортивних об’єктів і сертифікація спортивної зброї; стандартизація у сфері фізичної культури i спорту, зокрема стандартизація фізкультурно-спортивного спорядження й обладнання; здійснення реєстрації, обліку, експлуатації й нагляду за використанням і технічним станом плавальних засобів, що є спортивними суднами, спортивних автомобілів, спортивних мотоциклів, спортивних літальних апаратів; проведення обліку спортивної зброї; здійснення контролю за якістю фізкультурно-спортивних послуг і контролю за діяльністю закладів фізичної культури і спорту тощо.

На основі зазначеного ми пропонуємо доповнити Закон України «Про фізичну культуру $i$ спорт» розділол IV-I "Державне регулювання спорту», у яколу передбачити порядок здійснення управлінської та сервісної діяльності держави у сфері спорту.

\section{Jimepamypa}

1. Code du sport (Version au 31 mars 2011). URL: www.legifrance.gouv.fr/affichCode.do?cidTexte=LEGI TEXT000006071318\&dateTexte $=20110412$.

2. Чередник Р.В. Спорт як сфера правового регулювання: загальнотеоретичний аспект. Актуальні проблеми держави і права. С. 656-562.

3. Рибчич I.Є. Правові аспекти державного управління сферою фізичної культури і спорту в Україні. Державне будівниитво. 2015. № 1. С. 1-10. URL: http://www.kbuapa.kharkov.ua/e-book/db/2015-1/ doc/5/02.pdf.

4. Завальнюк О. Юридичні засади регулювання сучасної спортивної діяльності. Право. Серія 18 «Економіка і право». 2014. Вип. 26. С. 136-142. URL: file:///C:/ Users/VIP/Downloads/Nchnpu_018_2014_26_22\%20 (1).pdf.

5. Спорт на часі? Тенденції в законодавстві на 2019 рік. Юридична газета. URL: http://yur-gazeta. com/publications/practice/sportivne-pravo/sport-nachasi-tendenciyi-v-zakonodavstvi-na-2019-rik.html.

6. Бордюгова Г. Акти міжнародного спортивного законодавства як основа формування відповідної галузі міжнародного права. Віче. 2009. № 3. С. 12-14.

7. Нікітенко С.В. Особливості нормативно-правового регулювання фізичного виховання і спорту в Україні. Public administration and local government. 2016. № 1 (28). C. 95-100.

8. Пешин Н.Л., Бомановский Б. Правовые проблемы и особенности государственного регулирования спорта в России и Польше. Конституционное и лунииипальное право. 2012. № 11. URL: http://center-bereg. $\mathrm{ru} / \mathrm{f} 305 . \mathrm{html}$.

9. Алікова О.М. Організаційно-правові форми діяльності державних органів у сфері фізичної культури і спорту. Актуальні проблеми держави і права : збірник наукових праць. 2015. Вип. 25. С. 210-214.

10. Про фізичну культуру і спорт : Закон України від 24 грудня 1993 року № 3808-XII. Відолості Верховної Ради України. 1994. № 14. Ст. 80.

11. Законодавче та нормативно-правове забезпечення розвитку спорту вищих досягнень в Україні / М.П. Костенко, В.П. Карленко, А.В. Домашенко, Є.В. Імас та ін. Актуальні проблели фізичної культури i cnopmy. 2003. № 1. C. 13. 


\section{Анотація}

Капличний B. A. Недоліки Закону України «Про фізичну культуру і спорт». - Стаття.

У науковій статті визначено поняття нормативно-правового регулювання у сфері спорту. Здійснено аналіз нормативно-правового регулювання сфери спорту й виокремлено проблемні питання спеціального нормативно-правового акта - Закону України «Про фізичну культуру і спорт».

Визначено, що нормативно-правове регулювання у сфері спорту - це система законодавчих і підзаконних нормативно-правових актів, які врегульовують суспільні відносини щодо організації та проведення спортивних заходів і змагань, забезпечення рухової активності людей різних вікових груп і фізичного стану під час їхнього дозвілля для зміцнення здоров'я, сприяють інформаційній обізнаності населення щодо зайнятості спортивною діяльністю.

Система нормативно-правових актів у сфері спорту, на нашу думку, поділяється на міжнародні акти; норми фундаментальні, які визначать пріоритетність зайняття спортом, різні види спортивної діяльності, популяризують спорт на міжнародній арені та сприяють спортивному процвітанню й досягненням в спорті, і норми спеціального законодавства, тобто система актів, які врегульовують відносини щодо особливостей зайняття певним видом спорту, визначають та організовують порядок здійснення спортивної діяльності.

Доведено необхідність прийняття Указу Президента України «Про затвердження концепції з реалізації державної політики у сфері фізичної культури і спорту на період до 2025 року».

Суб'єкти публічного адміністрування сфери спорту - це система організаційно-структурних утворень, які наділені владними повноваженнями, на законних підставах здійснюють свою діяльність у сфері спорту з метою виконання покладених на них обов' язків i, відповідно, задоволення публічних інтересів щодо створення належних правових, економічних, організаційних, соціально-культурних умов для реалізації прав і свобод фізичних і юридичних осіб, забезпечення реалізації рівного доступу до фізкультурно-спортивної діяльності.

Ключові слова: фізична культура, фізкультура, спорт, здоров'я, фізичне виховання.

\section{Summary}

Kaplychnyi $V$. A. The Disadvantages of the Law of Ukraine "On Physical Culture and Sports". - Article.

This scientific article defines the concept of regulatory regulation in the field of sports. The analysis of the legal regulation of the sphere of sports is carried out and the problematic issues of a special regulatory legal act - the Law of Ukraine "On the Physical Culture of Sports" are singled out.

It is determined that the legal regulation in the field of sports is a system of legislative and by-law normative legal acts that regulate public relations regarding the organization and holding of sports events and competitions, ensuring the motor activity of people of different age groups and physical condition during their leisure for strengthening health, promote information awareness of the population about employment in sports activities.

In our opinion, the system of legal acts in the field of sports is divided into: international acts; fundamental rules that determine the priority of sports, define different types of sports activities, promote sports in the international arena and promote sporting prosperity and achievements and rules of special legislation, that is, a system of acts that regulate the relations with the specific features of sports, determine the type of sport the procedure for sports activities.

The necessity to adopt the Decree of the President of Ukraine "On approval of the concept on theimplementation of the state policy in the field of physical culture and sports for the period up to 2025 " has been proved.

The subjects of public administration of sports are a system of organizational and structural entities that are legally empowered to carry out their activities in the field of sports, with the aim of fulfilling their responsibilities and, accordingly, satisfying public interests in the creation of proper legal, economic, organizational, socio-cultural conditions for the exercise of the rights and freedoms of individuals and legal entities to ensure the realization of equal access to physical and sports activities.

Key words: physical culture, physical education, sports, health, physical education. 